2018, volume 7, issue 3

Piotrowski, D. (2018). Propaganda of success in the area of the state's social and economic policy. Copernican Journal of Finance \& Accounting, 7(3), 55-70. http://dx.doi.org/10.12775/ CJFA.2018.015

\author{
Dariusz Piotrowski* \\ Nicolaus Copernicus University in Toruń
}

\title{
PROPAGANDA OF SUCCESS IN THE AREA OF THE STATE'S SOCIAL AND ECONOMIC POLICY
}

Keywords: white propaganda, social policy, economic policy, ethics.

J E L Classification: H1, H3, H6, Z13.

\begin{abstract}
An attentive observer of the social and political life in Poland has certainly noticed changes in the way the government communicates with the public since the United Right (Zjednoczona Prawica) came to power at the end of 2015. Media messages, saturated with persuasive elements, have ceased to have an exclusively informative function. The government, with the help of the media, especially the public media, has begun to practise propaganda on a large scale. One of its manifestations is the impression created in the society that success has been achieved in the social and economic sphere. However, this is often at the expense of a breach of ethical standards in terms of content and form. The aim of this study is to examine whether and to what extent respondents critically analyse the content of media messages related to the "Family $500+$ " (Rodzina 500+) programme, as well as to the unemployment rate and the GDP dynamics. A survey conducted by the author shows that the government's propaganda has not been very effective in shaping the knowledge and attitudes of the interviewees. The limited effectiveness of such messages can be linked to the sources of information used by young people participating in the survey.
\end{abstract}

Date of submission: October 24, 2018; date of acceptance: January 11, 2019.

* Contact information: darius@umk.pl, Department of Finance Management, Faculty of Economic Sciences and Management, Nicolaus Copernicus University in Toruń, Gagarina 13a, 87-100 Toruń, Poland, phone: +48 5661146 34; ORCID ID: https://orcid. org/0000-0001-8482-8064. 


\section{INTRODUCTION}

Making responsible decisions in the area of the state's social and economic policy requires an appropriately high level of economic imagination among the society. A.K. Koźmiński refers to it as economic knowledge derived from literature, media, one's own observations and experience, in the shaping of which "soft" elements of economic systems, such as ethics, ideology, politics, emotions, irrational individual and collective choices, as well as misrepresentations and information noise, play an important role (Koźmiński, 2016, p. 28). Unfortunately, results of many national and international surveys indicate an unsatisfactorily low level of financial awareness among Poles (OECD, 2016, p. 8; PISA, 2017, pp. 150-160; Iwanicz-Drozdowska, 2011, pp. 181-191). It can be assumed that erroneous behaviour and attitudes of individuals observed in the area of finance are an element of a wider phenomenon, referred to by T. Mickiewicz as political ignorance. Mickiewicz notes that, despite the significance of the matters related to the state's social and economic policy, individuals are not willing to devote sufficient time and resources to obtain the necessary knowledge needed in the area of political decisions (Mickiewicz, 2012, p. 102). This fact is being recognised by the politicians who try to use it to achieve their own goals (Somin, 2013). Through mass media, those in power try to influence the perception and evaluation of economic phenomena by the society (Chomsky, 2002; Croteau \& Hoynes, 2018).

\section{THE RESEARCH METHODOLOGY}

\section{AND THE COURSE OF THE RESEARCH PROCESS}

The aim of this study is to examine whether and to what extent respondents critically analyse the content of media messages related to the "Family 500+" (Rodzina 500+) programme, to the unemployment rate and the GDP dynamics, i.e. the areas described by the media as the achievements of the "good change" (leading party's campaign slogan). The following research hypothesis was adopted in this paper: the propaganda of success of the United Right's government in the area the state's social and economic policy is highly effective in shaping opinions and attitudes among the respondents. The aim of the study has been reached and the research hypothesis has been verified on the basis of a critical analysis of the source literature, the analysis of data pertaining to the social and economic situation in Poland, the analysis of media messages 
related to social and economic issues and the results of a survey conducted by the author.

\section{PROPAGANDA AS A SPECIAL FORM OF POLITICAL COMMUNICATION}

In the source literature, the model of an economic man, acting rationally, is presented against the model of a social man, functioning within various social groups which influence his behaviour and attitudes (Wu, 2017; Zafirovski, 2000, pp. 7-30; Cicognani \& Zani, 2015, pp. 124-145). In reality, actions of individuals fall between these two extremes and manifest themselves in limited or selective rationalism and in choices that are satisfactory in terms of their degree of usefulness (Klimczak, 2008, pp. 35-38). In both models, information plays an important role, which G. Gilder compares to a surprise that brings about a change in the level of knowledge, as compared to its level from before the transmission of the information (Gilder, 2016, pp. 39-40). Depending on the purpose of the information stream, a distinction is made between messages and propaganda. Messages increase the amount of knowledge one has. The recipients, based on their current knowledge and experience, make their own assessment of the content. The sender also refrains from interfering with the reasoning process. In case of propaganda, the intention of the propagandist is to influence the recipient of the message. More or less openly, the message suggests how events, social processes and economic data should be interpreted and what attitude towards them should be assumed (Black, 2001, pp. 121-137).

Information is an integral part of political communication and can be used in the process of social control or the control of public perception of a phenomenon. Political communication is aimed at achieving the objectives of the message originator, which usually include shaping the behaviour and attitudes of the addressees of the message. As part of this process, rational and non-rational factors are used, and through the history of human civilisation the latter has been favoured, for example factors related to instinct and emotions (Pawełczyk, 2007, pp. 106-111). The control itself can take the form of persuasion, manipulation, coercion or violence (Mikołajewski, 2010, pp. 175-189).

As mentioned above, one form of political communication is propaganda. In general, propaganda can be described as organised mass persuasion, characterised by an almost unidirectional flow of information (Pawełczyk \& Piontek, 1999, pp. 38-40). According to source literature, propaganda was originally neutral and meant spreading or promoting certain ideas. Over time, the term 
has gained negative meaning and is used as an alternative to such words as manipulation, distortion, deception, mind control, or brainwashing (Henderson, Braun, Adams, Bazerman, Chaput \& Dunmire, 2016). The term "propaganda", as understood by G.S. Jowett and V. O'Donnell, is the deliberate, systematic attempt to shape perceptions and manipulate cognitions to achieve a result that is coherent with the desired intent of the propagandist (Jowett \& O'Donnell, 2012, pp. 2-7).

In a narrower sense, political propaganda is "one of the forms of communication remaining in systemic relations to the authorities, ideologies, media and the public opinion" (Dobek-Ostrowska, Fras \& Ociepka, 1999, p. 6). Political propaganda involves mobilising large social groups around an ideology. According to M. Nieć, the key element of propaganda is the originator of the message, being an organised entity (political party, state, church) and pursuing its goals which bring it closer to achieving political power or to its strengthening (Nieć, 2013, p. 85). Propaganda manifests itself in targeted dissemination of information, opinions and views explaining the reality and the phenomena of social life in a manner consistent with the interests of those in power (Kula, 2005 , p. 82). However, unlike political agitation or advertising, propaganda is aimed at achieving a change in attitudes rather than at a direct political response (Nieć, 2013, p. 147).

One of the most important criteria for the assessment of political propaganda is its effectiveness in shaping the knowledge, behaviour and attitudes of the recipients in line with the expectations of the originator of the message (Tokarczyk, 2011, pp. 87-102). The effectiveness of propaganda can be improved by the use of techniques relating to the form and content of the message. The growing importance of mass media in the life of societies, which has been observed for decades, helps the message reach a wide audience (Woolley \& Howard, 2016, pp. 4882-4890). As regards the content of the message, propaganda imposes the conditions and the subject of the debate and uses techniques such as: multiple repetitions, half-truths, generalization of one-off phenomena and exaggeration of details, as well as total negation combined with ironic and hypocritical praise (Znyk, 2011, pp. 29-30). However, the use of such techniques is often in conflict with the ethics, understood by Sz. Wojdyła as compliance with the primary moral standards, while the ethical nature of a given action lays in its credibility, soundness, honesty and integrity (Wojdyła, 2014, pp. 43-52). 


\section{STATE'S SOCIAL AND ECONOMIC POLICY AS A SUBJECT OF WHITE PROPAGANDA}

Many months of analysis of the content of the messages and the way that the United Right's government and the public media favourable to it communicate with the society as regards the social and economic policy indicate the use of propaganda ${ }^{1}$. White propaganda is being practised with regard to the government's achievements. In this case, the source of the message can be accurately identified and the information contained in the message is close to the truth. As noted by B.A. Patrick, the use of blatant lies in propaganda can undermine the credibility of the source if it is detected. It may therefore be more effective to create a message based on the truth, selected facts, statistics or arbitrarily adopted definitions (Patrick, 2015, p. 27). The way it is presented is aimed at building a positive perception or credibility among the addressees. In relation to the social and economic phenomena analysed further in this paper, the aim of propaganda was to shape, strengthen or change the views and behaviours of the addressees of propaganda, so that they are compliant with those of the originator of the message, in this case - the Polish government. The use of white propaganda has served to gain acceptance, approval or even support for the current and future actions of the government and the parliamentary majority.

The first issue analysed in the paper is the "Family 500+" programme. Initial plans concerning this programme were announced in the course of the presidential and parliamentary campaign in 2015. The programme's main objective, defined as the increase in the number of births, could be seen as exceptionally relevant, considering that Poland is facing the problem of its aging population. The scale of the demographic threat is presented by the UN forecast according to which, over the next 40 years, the population of Poland

1 The United Right is a coalition of three parties, the most important of which is Law and Justice. This party, just like the second force in the Polish Parliament-the Civic Platform, has an anti-communist background. The Civic Platform, which co-ruled the country in the years 2007-2015, is a group that endorses economic liberalism, advocating Poland's membership in the structures of the European Union. Law and Justice is a party that can be characterised by conservatism and populism. The party won the 2015 elections owing to a good social agenda, but also thanks to the skilful use of social engineering. Following the takeover of the public media, the party has been engaged in propaganda on a scale unprecedented in democratic countries. 
would decrease from about 38 to 30 million inhabitants. At the same time, from the point of view of the economy and the public finances there are very unfavourable changes approaching in the age structure of the population. The ratio of the number of people aged 15-64 to the number of people aged 65 and over, which is currently 4, will decrease to about 1.5 in 2060 (United Nations, 2017). The main reason for the growing demographic problem is the low fertility rate, which in Poland was at about 1.3 children per woman of childbearing age at the time the programme was launched, with the value of about 2.1-2.15 being required to maintain simple replacement of generations. The programme which consists of a monthly payment of PLN 500 (about EUR 120) from the state funds for each second and subsequent child was introduced in April 2016².

As soon as at the time of its introduction, the programme was presented in the public media as the current government's success. Even greater strengthening of the propaganda and an increase in the frequency of messages directed to the public concerning the implementation of the programme was paired with the presentation of further optimistic data concerning the number of births in Poland. In 2016, about 382 thousand children were born in Poland, while in 2017 the number of births amounted to 402 thousand. Media reports stressed the increase in the number of births compared to 2015, when this figure stood at about 369 thousand (Central..., 2017). In early 2017, the then Prime Minister, Beata Szydło, described the situation as "baby boom". She even suggested that there was a need to find a Polish equivalent for the phrase. It is also worth noting that, while the programme was in operation, the media increasingly emphasised its positive impact on the reduction of poverty among Polish families.

The author's critical analysis of the principles of the "Family 500+" programme and its results differs significantly from the image presented in the media and shows low effectiveness of the government's programme. First, the government deliberately avoids making comparisons with the past, when Poland was actually experiencing a demographic boom. In the 1950s the number of live births was sometimes close to 800 thousand, and in the first half of the 1980s it slightly exceeded 700 thousand. Recently, however, in the years 2008-2010, the number of births was about 414 thousand, 418 thousand and

2 Obtaining support for the first child is possible if the family's monthly income per person does not exceed approximately EUR 190. 
413 thousand, respectively (Central..., 2017). Therefore, if the values indicated here were unsatisfactory, then the number of births recorded in 2016-2017 cannot be the basis for proclaiming the success of the programme. Secondly, the programme is very expensive and, at the same time, characterised by low effectiveness. Over the first two years, approximately PLN 42 billion (nearly EUR 10 billion) was spent on its operation. The programme has resulted in an increase in the number of births, as compared to the base year 2015, by only about 46 thousand in the scale of two years. Thirdly, the programme is poorly designed, as it rewards the fact of having children but gives little incentive to families to increase the number of children they have. It is therefore necessary to change the focus of the programme and the financial support provided ${ }^{3}$. The programme also fails to promote a change in the lifestyle of young couples, as in the current legal situation obtaining state support after the birth of the first child is practically impossible. Fourthly, the government's programme is socially unjust. Due to the fact that there is no upper income limit, the programme benefits the rich who, by applying certain accounting measures in their companies, can receive support for all the children they have. On the other hand, the lower income limit for obtaining support for the first child means that people in a difficult situation who are raising one child as single parents and whose monthly earnings exceed EUR 380, cannot count on the state's financial support. Fifthly, the government, probably seeing the unsatisfactory effects of the programme on the number of births, points to the reduction of poverty in the society as the major achievement. However, the reduction of poverty does not directly lead to an increase in the birth rate. Moreover, the government fails to point out that the programme is largely financed by public debt and the funds used will sooner or later have to be reimbursed ${ }^{4}$.

${ }^{3}$ A couple with three children can, depending on its income, count on monthly state support in the amount of PLN 1,000 or PLN 1,500. This creates high costs for the state. At the same time, it is difficult to expect that the mother of these children, who may be 40 years old, will decide to have another child in exchange for an additional PLN 500 a month.

42016 saw the largest annual increase in the public debt, in the amount of PLN 94 billion, recorded in the history of Poland. This amount would be sufficient for four years of operation of the "Family 500+" programme. 
Figure 1. Unemployment rate in Poland in years 2007-2017

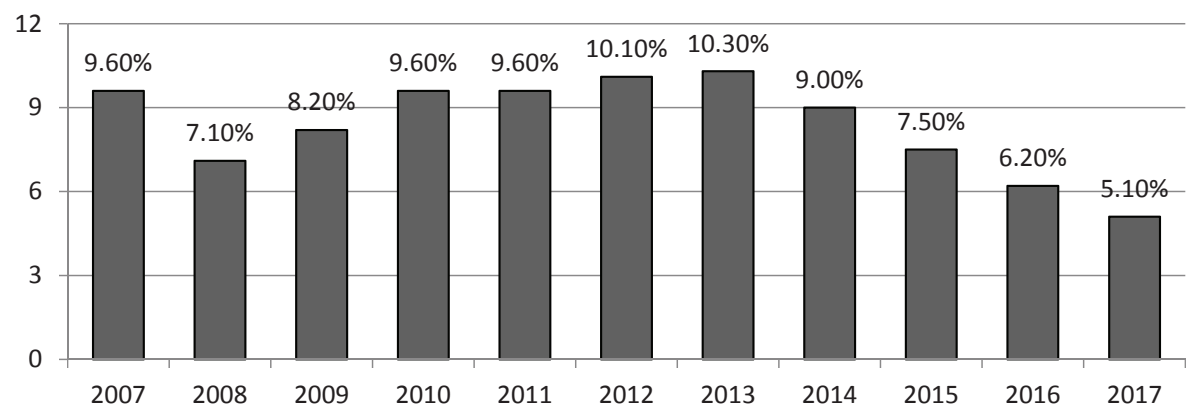

S o u r c e : Eurostat.

Another issue analysed in this study is the unemployment rate. Data indicating its recent decline is periodically reported in the media. Public media are particularly keen on highlighting the fact that the unemployment rate is exceptionally low, being an indication of a good situation on the labour market which has been achieved since the United Right came to power. However, when analysing the data presented in figure 1 , one can notice that the downward trend in the unemployment rate started in 2014. On the other hand, the analysis of legal regulations concerning Poland's employment market indicates lack of any measures or programmes pursued by the current authorities aimed at increasing Poles' activity on the job market. It is therefore difficult to attribute this success to the government of the United Right. More importantly, however, it is debatable whether the current situation can be seen as success. The decreasing unemployment rate in Poland has for some time ceased to be a desirable phenomenon for the economy, or rather it poses a threat to its further development. There are several reasons for this. Firstly, Poland is diversified in terms of its development. This division has been determined by history. It can be assumed, with certain simplification, that the regions to the west of Vistula, the main river of Poland, are more economically developed than the regions located to its right. An analysis of the average level of the unemployment rate in Poland may lead to a wrong conclusion that there are reserves of labour force which can be used in the event of high dynamics of the country's economic development. In fact, however, in the more developed regions of the main economic centres, the unemployment rate has come close to its natural level and there are huge difficulties reported in finding employees. This problem will not be solved by the inflow of people seeking work from the eastern regions of Poland, as Poles are 
not very willing to change their residence for the purpose of new employment. Secondly, Poland has a high level of structural unemployment. This means, on the one hand, that, according to the preliminary data of the Ministry of Family, Labour and Social Policy, the number of the unemployed registered as such at the end of August 2018 was 959.5 thousand, which was the lowest result since September 1990. On the other hand, the economy is in need of a total of hundreds of thousands of construction workers, lorry drivers, engineers, doctors, IT specialists, etc. Thirdly, the prospects of the labour market in Poland are very adversely influenced by demographic processes (people born during the baby boom of 1950s are retiring and are being replaced by the generation born during the demographic decline of 1990s), as well as regulatory changes (the lowering of the retirement age introduced by the current government and the introduction of the "Family 500+" programme which discourages people from taking up or maintaining employment).

Figure 2. The growth of GDP in Poland in years 2011-2017

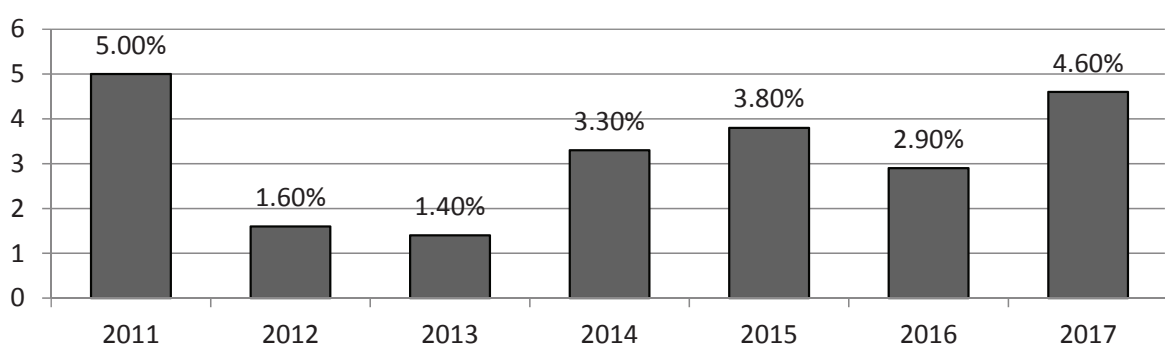

S o u r c e : Central Statistical Office.

The third and last area of government propaganda analysed in this study is the high dynamics of Poland's GDP. The government is priding itself on the level close to 5\%, ignoring the fact that the trend collapsed in 2016. It also gives examples of foreign investments carried out in Poland, which are meant to give evidence of its good management of the country's affairs and foreign investors' trust in the current administration. According to the author of this study, among the cases analysed, the propaganda concerning the achievements of the government as regards the GDP dynamics is the closest to the truth. However, the media techniques used by the government give raise to serious questions about the ethics of the communication in this area as well. The analysis of the data presented in figure 2 shows that the level of $4.6 \%$ achieved in 2017 is rel- 
atively high, as compared to the other years. It should be borne in mind, however, that in 2011 the economy grew by 5\%, even though the world had barely managed to recover from the financial crisis and Europe just about to face the problem of euro area countries' debt crisis. The result recorded in 2017, although theoretically high, may be unsatisfactory. What is important for its assessment is the analysis of the market environment and the conditions in which this result was achieved. Stable situation on the financial markets, low interest rates, low prices of raw materials, stable exchange rates, access to huge funds from the European Union, as well as the increase in domestic demand fuelled by social programmes are factors due to which a much higher result could have been expected. One of the reasons why the potential created by market conditions is not being realised is a very low level of investment. The government is trying to hide this fact by highlighting individual investments, thus uses manipulation.

\section{PRESENTATION OF SURVEY RESULTS}

The verification of the research hypothesis is based on the results of the author's own research conducted in the form of a questionnaire in March 2018 among first year Management students at the Faculty of Economic Sciences and Management of Nicolaus Copernicus University in Toruń. The survey involved 90 respondents who were asked questions meant to determine their level of knowledge and attitudes towards the state's economic policy, as well as aimed to reveal their sources of information in the areas covered by the survey. The advantage of the survey was the fact that the respondents had acquired knowledge on the matters in question on their own, as the survey was conducted before the analysis of Poland's social and economic situation during university classes. Consequently, the knowledge and views of the respondents somehow showed a certain image of the Polish society. However, what distinguished the respondents from the general society was the fact that they were obtaining university education and their young age, under 20 years old.

The survey was carried out in a wide range of areas, including the state's social and economic policy and the condition of the public finances. For the purpose of this work, answers to 6 out of 18 questions were used. The responses were analysed in terms of radicalism or moderate nature of the views expressed, and respondents' identification with extremely positive opinions was interpreted as the influence of propaganda. 
Three questions included in the questionnaire referred to the issues related to the "Family 500+" programme. The answers to these questions are shown in figures 3 and 4 .

Figure 3. Sentence that in best way describes the "Family 500+" programme

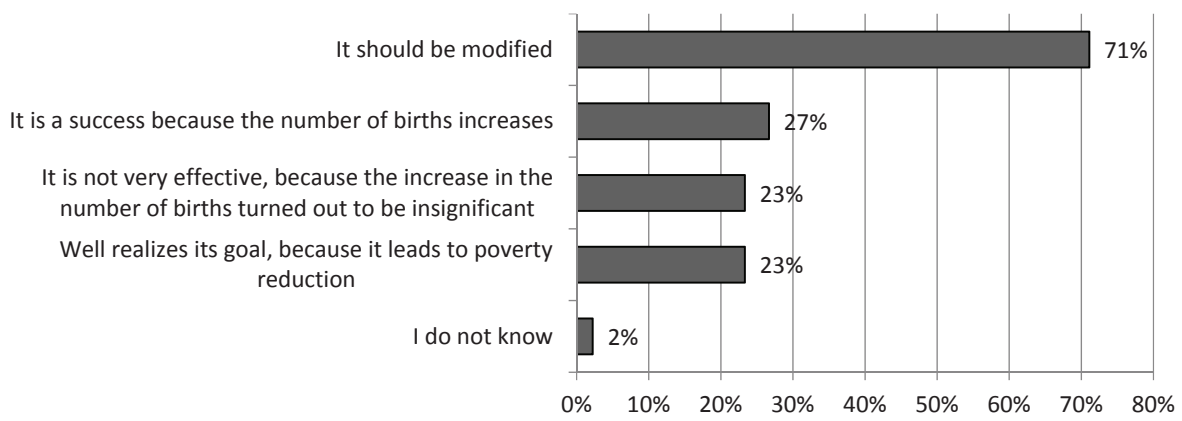

S o u r c e : author's own survey, $\mathrm{N}=90$, multiple choice.

The analysis of figure 3 shows that the respondents are well aware of the weak points of the "Family 500+" programme. The answers indicating the need to modify the programme, as well as pointing to its low effectiveness due to a small increase in the number of births, prevailed over the other answers. It can therefore be concluded that the influence of the government propaganda in this area on this group of respondents had been limited.

The analysis of answers presented in figure 4 shows that the level of knowledge about Poland's demography among the respondents is unsatisfactory. This can be explained by the fact that the government deliberately misleads the public. The propaganda message emphasises the fact that the number of births has increased, however, without mentioning the number of births in preceding years or decades (except 2015), as, if given the opportunity to make the comparison, the society would easily notice the low effectiveness of the "Family $500+$ " programme in achieving its main objective. 
Figure 4. Number of births of children in Poland, according to the respondents' opinions

In 2016-2017

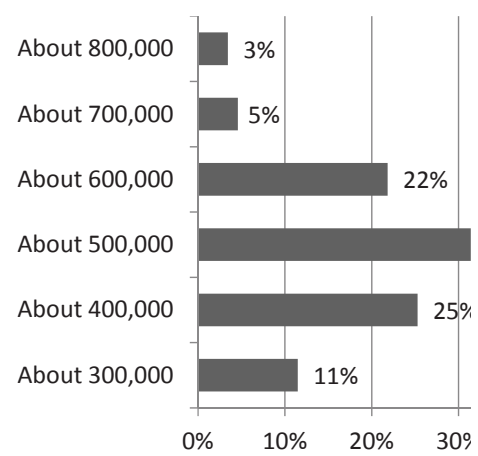

In the 1950 s

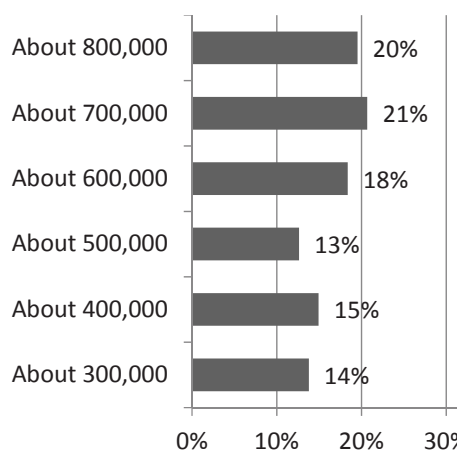

S o u r c e : author's own survey, $\mathrm{N}=87$.

Figure 5. Respondents' opinion on the reduction of the unemployment rate

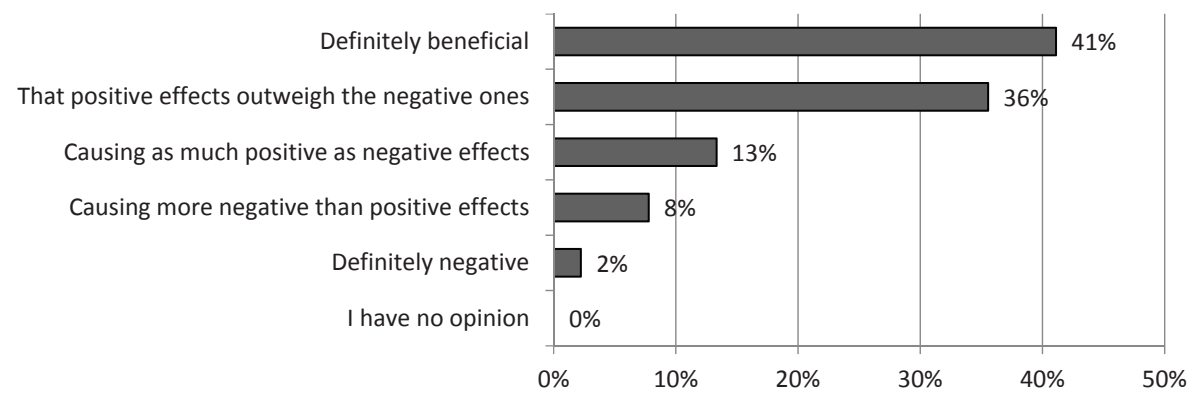

S o u r c e : author's own survey, $\mathrm{N}=90$.

With reference to the data presented in figure 5 , it can be concluded that the impact of the propaganda on the respondents as regards the interpretation of the decreasing unemployment rate is more visible than in the case of the family support programme. Most of the answers provided were of extremely positive nature (41\%). According to the author, this may indicate a lack of critical analysis of the matter in question or lack of sufficient knowledge among this group of respondents about multidimensional effects of decreasing unemployment rates on the economy. However, if we take into account the fact that three 
different subsequent answers are of a moderate nature, it turns out that most respondents (57\%) are able to make an independent assessment of Poland's social and economic situation, different from the assessment presented in propaganda messages.

Figure 6. Respondents' opinion on GDP dynamics in Poland in 2017

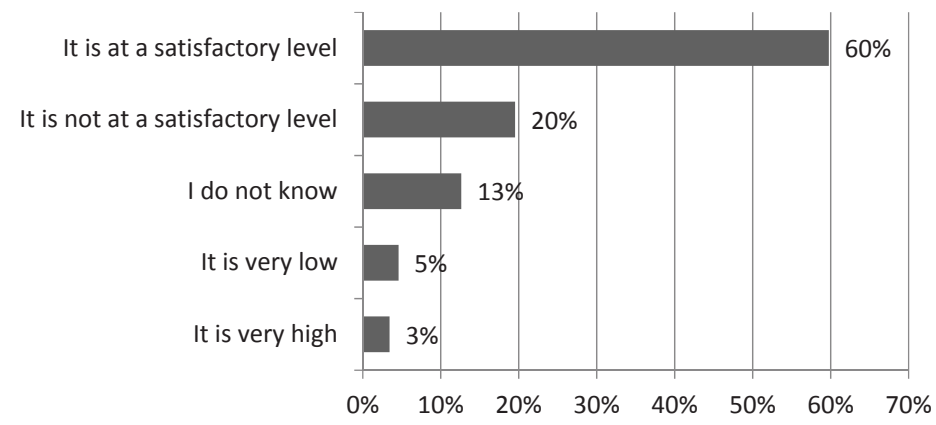

S o u r c e : author's own survey, $\mathrm{N}=87$.

As regards the GDP dynamics, only 3\% of the respondents provided answers that could have been influenced by the propaganda. As many as $80 \%$ of respondents expressed moderate optimism in the analysed area.

The last question included in the survey was meant to identify the respondents' sources of information in the area of the state's social and economic policy. Figure 7 presents the information sources as viewed by the respondents: from the most important to the least important.

It appears that young people participating in the survey prefer modern forms of obtaining information. Internet information services and social media are featured as the most important. Next are traditional forms of mass media, i.e. television and radio. The respondents pointed to personal exchange of views among family and friends as the least important source of information. 
Figure 7. Importance of the source of obtaining information by respondents

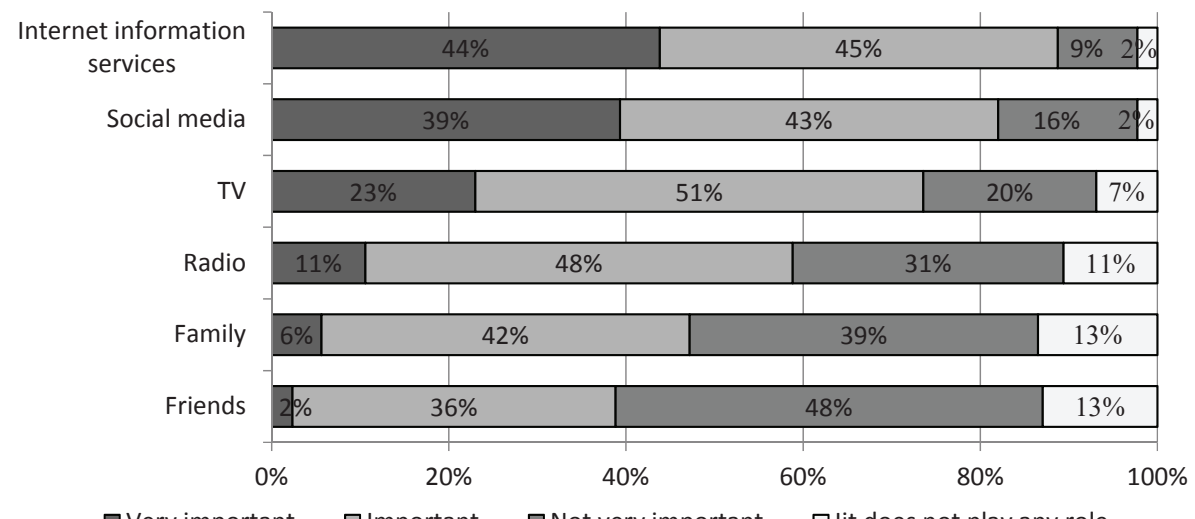

S o u r c e : author's own survey, $\mathrm{N}=85-89$.

\section{ConCLUSIONS}

During the socialist period, government propaganda tried to add colour to the then grey life in Poland. However, over the years under the authoritarian governments, the society developed defence mechanisms against the flood of false or manipulated information. For a significant part of the society, the beginning of the Polish economic transformation also meant the end of large-scale propaganda practised by the authorities. However, these people were wrong as for almost three years, the old style of communication between the government and the society, devoid of ethics, has been present again. Analyses of the social and political life in Poland, and in particular opinion polls measuring social support for political parties, show that a large part of the society believes in vision of the reality as presented by those in power.

Surveys conducted for the purpose of this study showed that the effectiveness of the government propaganda in relation to the respondents was low. The respondents critically analysed the measures undertaken within the framework of Poland's social and economic policy. The vast majority of the interviewees did not share the optimism or the atmosphere of success created by the government propaganda. According to the author, three main factors of limited effect of the propaganda on this group of people can be identified. First, they were young people, open to different political views and critical of the information commu- 
nicated to them. Secondly, the respondents' desire to acquire knowledge, combined with the ease with which they could obtain it using modern means of communication, made them resistant to one-sided propaganda messages. Thirdly, obtaining information by respondents mainly through on-line information services and social media made it difficult for the government propaganda to reach this group of people. The easiest way for such propaganda to reach its addressees is through public media which in Poland include television and radio.

\section{REFERENCES}

Black, J. (2001). Semantics and Ethics of Propaganda. Journal of Mass Media Ethics, 16(2\&3), 121-137.

Central Statistical Office (2017). Demographic Yearbook of Poland 2017. Warsaw: Central Statistical Office.

Chomsky, N. (2002). Media control: the spectacular achievements of propaganda. New York: Seven Stories Press.

Cicognani, E., \& Zani, B. (2015). Social and psychological factors influencing political and civic participation: A psychosocial perspective. In M. Barrett, B. Zani (Eds.). Political and Civic Engagement: Multidisciplinary Perspectives. Routledge: London.

Croteau, D., \& Hoynes, W. (2018). Media/Society: technology, industries, content, and users. Thousand Oaks: SAGE Publications.

Dobek-Ostrowska, B., Fras, J., \& Ociepka, B. (1999). Teoria i praktyka propagandy. (Theory and practice of propaganda.) Wrocław: Wydawnictwo Uniwersytetu Wrocławskiego.

Gilder, G. (2016). Wiedza i władza. Informacyjna teoria kapitalizmu i wywołana przez niq rewolucja. (Knowledge and power. The informational theory of capitalism and the revolution it triggered.) Poznań: Zysk i S-ka Wydawnictwo.

Henderson, G.L., Braun, M.J., Adams, L.L., Bazerman, C., Chaput, C., \& Dunmire, P. (2016). Propaganda and rhetoric in democracy: history, theory, analysis. Carbondale: Southern Illinois University Press.

Iwanicz-Drozdowska, M. (Ed.) (2011). Edukacja i świadomość finansowa. Doświadczenia i perspektywy. (Education and financial awareness. Experience and perspectives.) Warszawa: Oficyna Wydawnicza Szkoła Główna Handlowa w Warszawie.

Jowett, G.S., \& O'Donnell, V. (2012). Propaganda and Persuasion, London: SAGE.

Klimczak, B. (2008). Między ekonomiq a etyka. (Between economics and ethics.) Wrocław: Wydawnictwo Uniwersytetu Ekonomicznego we Wrocławiu.

Koźmiński, A.K. (2016). Wyobraźnia ekonomiczna. (Economic imagination.) Warszawa: Wydawnictwo Poltext.

Kula, H.M. (2005). Propaganda współczesna. Istota - właściwości. (Contemporary propaganda. Essence - properties.) Toruń: Wydawnictwo Adam Marszałek.

Mickiewicz, T. (2012). Wybór w gospodarce: wprowadzenie do ekonomii. (Choice in the economy: an introduction to economics.) Kraków: Konsorcjum Akademickie. 
Mikołajewski, K. (2010). Pragmatyczne i moralne granice sterowania politycznego. Ujęcie systemowo-cybernetyczne. (Pragmatic and moral limits of political control. Systemcybernetic approach.) Warszawa: Dom Wydawniczy ELIPSA.

Nieć, M. (2013). Komunikowanie polityczne w nowoczesnym państwie. (Political communication in a modern state.) Warszawa: Wolters Kluwer.

OECD (2016). OECD/INFE International Survey of Adult Financial Literacy Competencies, http://www.oecd.org/daf/fin/financial-education/OECD-INFE-InternationalSurvey-of-Adult-FInancial-Literacy-Competencies.pdf (accessed: 20.06.2018).

Patrick, B.A. (2015). 10 przykazań propagandy. (10 commandments of propaganda.) Gliwice: Helion.

Pawełczyk, P. (2007). Socjotechniczne aspekty gry politycznej. (Social engineering aspects of the political game.) Poznań: Wydawnictwo Naukowe UAM.

Pawełczyk, P., \& Piontek, D. (1999). Socjotechnika w komunikowaniu politycznym. (Social engineering in political communication.) Poznań: Wydawnictwo Naukowe Instytutu Nauk Politycznych i Dziennikarstwa UAM.

PISA (2017). PISA 2015 Results (Volume IV): Students' Financial Literacy, http://www. oecd.org/education/pisa-2015-results-volume-iv-9789264270282-en.htm (accessed: 11.06.2018).

Somin, I. (2013). Democracy and political ignorance: why smaller government is smarter. Stanford: Stanford Law Books, an imprint of Stanford University Press.

Tokarczyk, R. (2011). Moralność polityka w świetle myśli politycznej jako podstawy regulacji etycznych. (Politics morality in the light of political thought as the basis for ethical regulation.) In J. Justyński, A. Madeja (Eds.). Moralność $i$ władza jako kategorie myśli politycznej. (Morality and power as categories of political thought.) Warszawa: LEX a Wolters Kluwer business.

United Nations (2017). World population prospects: the 2017 revision, http://esa. un.org/unpd/wpp/Graphs/DemographicProfiles (accessed: 3.07.2018).

Wojdyła, Sz. (2014). Obietnice wyborcze a etyka - co można obiecać a co zrealizować? Wybrane obietnice wyborcze polskich partii politycznych. (Election promises and ethics - what can be promised and what to do? Selected election promises of Polish political parties.) In M. Rączkiewicz (Ed.). Mechanizmy obietnic. Kampanie i system wyborcze na świecie. (Mechanisms of promises. Campaigns and the electoral system in the world.) Łódź: Wydawnictwo Uniwersytetu Łódzkiego.

Woolley, S.C., \& Howard, P.N. (2016). Political Communication, Computational Propaganda, and Autonomous Agents. International Journal of Communication, 10, 4882-4890 .

Wu, G. (2017). Globalization against democracy: a political economy of capitalism after its global triumph. Cambridge: Cambridge University Press.

Zafirovski, M. (2000). Economic and sociological approaches to institutions: economy, society and law. European Journal of Law and Economics, 10(1), 7-30. http://dx.doi. org/10.1023/A:1018734704509.

Znyk, P. (2011). Propaganda - współczesne oblicza. Technologia zabójstwa medialnego. (Propaganda - contemporary faces. Media killing technology.) Łódź: Bracia Zybert APR „Gryf” s.c. 